Int. J. Morphol.,

33(1):318-326, 2015.

\title{
Biomechanical Evaluation of a Spinal Screw Fixation System by the Finite Element Method
}

\author{
Evaluación Biomecánica de un Sistema de Fijación Espinal \\ con Tornillo por el Método de Elementos Finitos
}

Ana Paula Macedo*; João Paulo Mardegan Issa**; Helton Luiz Aparecido Defino*** \& Antonio Carlos Shimano ${ }^{* * * *}$

MACEDO, A. P.; ISSA, J. P. M.; DEFINO, H. L. A. \& SHIMANO, A. C. Biomechanical evaluation of a spinal screw fixation system by the finite element method. Int. J. Morphol., 33(1):318-326, 2015.

SUMMARY: The objective of the present study was to validate virtual models for the study of dual core and cylindrical screws and evaluate the influence of the geometry of the screws on the mechanical behavior and anchoring. Two models of dual core screws were used, one with a double thread and the other with a single thread, both with a conventional cylindrical screw were used in this study. The stiffness was assessed in a pullout test using polyurethane. Three dimensional virtual models simulating the pullout test were created for finite element analysis. To validate the models, the results were correlated with the mechanical tests. Tensions generated in polyurethane and the screw were studied while simulating the application of force in the direction of the screw pullout, of force transmitted by the rod with the individual standing at rest, and the force transmitted by the rod when performing flexion of the trunk. The dual core screws generated lower tensions in the polyurethane when compared to the cylindrical screw for the forces studied. When evaluating internal tension in the screw, lower levels of tension were presented in the dual core - double thread, higher levels were observed in dual core single thread, this screw has a smaller internal diameter which may be responsible for this higher generated tension. The dual core screws double thread proportionated good anchorage with more diameter on the region with great tension, avoiding the fracture.

KEY WORDS: Bone screws; Spine fixation devices; Finite element analysis.

\section{INTRODUCTION}

The use of internal fixation of the vertebral column has allowed the realization of more rapid arthrodesis and better deformity correction without the need for external immobilization. The mechanical performance of a vertebral fixation system is highly dependent on its biomechanical characteristics and the maintenance of strength of the vertebral screw interface (Chen et al., 2003a, 2003b; Hackenberg et al., 2002; Kostuik et al., 1994). Screw resistance to fracture, flexure, and high resistance to pullout have been widely used as anchoring elements of vertebral fixation systems. However, the loss of stability of the spinal fixation system can be affected by loosening or fracture thereof. Thus, the interface between the screw and the vertebral bone plays an important role in the biomechanical stability of the spinal fixation system and can interfere with the final outcome (Brantley et al., 1994; Coe et al., 1990; George et al., 1991; Hirano et al., 1997).

Failure of screw fixation is a clinical problem commonly seen in vertebral spine surgeries (Law et al., 1993). Screw fixation on the vertebra depends on several factors related to the bone in which it is deployed (bone mineral density), the type of screws used (design, outer diameter, pitch and thread height) and the technical preparation of the pilot hole (diameter, tapping and drilling tool) (Hsu et al., 2005; Lill et al., 2006; Zdeblick et al., 1993).

* Department of Biomechanics, Medicine and Rehabilitation of the Locomotor Apparatus, Faculty of Medicine of Ribeirão Preto, University of São Paulo, São Paulo, Brazil.

*** Associate Professor, Department of Morphology, Physiology, and Basic Pathology, School of Dentistry of Ribeirão Preto, University of São Paulo and Department of Biomechanics, Medicine and Rehabilitation of the Locomotor Apparatus, Faculty of Medicine of Ribeirão Preto, University of São Paulo, São Paulo, Brazil.

**** Full Professor, Department of Biomechanics, Medicine and Rehabilitation of the Locomotor Apparatus, Faculty of Medicine of Ribeirão Preto, University of São Paulo, São Paulo, Brazil.

***** Associate Professor, Department of Biomechanics, Medicine and Rehabilitation of the Locomotor Apparatus, Faculty of Medicine of Ribeirão Preto, University of São Paulo, São Paulo, Brazil. 
The literature presents several studies that compare the mechanical resistance of conical and cylindrical screws (Abshire et al., 2001; Hsu et al.; Inceoglu et al., 2004; Kwok et al., 1996; Ono et al., 2001). Some studies report that conical screws have greater pullout resistance and better grip than cylindrical screws (Krenn et al., 2008). However, the study by Krenn et al. reported a higher binding capacity of cylindrical screws compared to conical screws. Recently some studies using dual core screws have observed good fixation in vertebra (Lill et al.). However, these screws do not present more resistance to tearing when compared to the cylindrical or conical screws (Lill et al.; Seller et al., 2007). Therefore, this study aimed to validate virtual models for the study of dual core and cylindrical screws and evaluate the influence of the geometry of the screws on the mechanical behavior and anchorage, and verification of which might provide better fixation over time.

\section{MATERIAL AND METHOD}

Two dual core model screws, one with single thread for anterior fixation and one with double thread with a conventional cylindrical screw, used in both posterior and anterior fixation (Synthes®, Davos, Switzerland) were used in this study (Table I).

Rigid polyurethane blocks were validated by the American Society for Testing Materials (ASTM), which found that this material has mechanical properties that mimic human cancellous bone. This society considers rigid polyurethane a standard material for performing mechanical tests on rigid orthopedic implants. Synthetic bone offers advantages such as homogeneity of the samples and better reproducibility when compared with the biological material.

Stiffness. The stiffness of each model screw was obtained through a 'mechanical' pullout test using polyurethane (Nacional Ossos®, Jau, SP, Brazil) with a density of $0.16 \mathrm{~g} /$ $\mathrm{cm}^{3}$, modules of elasticity $0.023 \mathrm{GPa}$ and Poisson's ratio 0.3 . For this, 30 blocks of polyurethane of $24 \times 24 \times 42 \mathrm{~mm}$ were made. These were divided into three groups, being G1: dual core screw - double thread, G2: dual core - single thread, and G3: cylindrical screw. The screws were inserted through a hole in the pilot blocks produced by a probe with $3.8 \mathrm{~mm}$ diameter, as recommended by the manufacturer. A guide was used to ensure the perpendicularity of the screw relative to the surface of the block. The mechanical pullout tests were performed using a universal testing machine (EMIC® - DL 10000, São José dos Pinhais, Brazil) with a load cell of 2000 N. Blocks with screws inserted were placed on a platform and pullout force $(\mathrm{F})$ was applied vertically to the bolt head, at a rate of $2 \mathrm{~mm} / \mathrm{min}$ (Fig. 1). The force curve (N) x displacement $(\mathrm{mm})$ was obtained by the Tesc 3.13 program (EMIC, Brazil) and in this way the stiffness was obtained.

Validation of Virtual Models. Three virtual three-dimensional models simulating the pullout test were created in ANSYS WorkBench ${ }^{\circledR} 10.0$ software (ANSYS Inc. Canonsburg, USA) for analysis by the finite element method. Three-dimensional mesh models with tetrahedral elements were generated and analyzed in the program. The elements SOLID186, SOLID 187, CONTA170 E and TARGE170 were used. All components were considered homogeneous and isotropic. Table II shows the modulus of elasticity (E) and Poisson's ratio (n) of the materials used in the simulation. Simulating pullout and stiffness of the models was performed for comparison with the 'mechanical' forces test. After comparing the results and validating the models, a study of the tension generated in polyurethane and in the screw to simulate the application of pullout strength, compression, and flexion was performed.

Pullout. A force of $50 \mathrm{~N}$ in the direction of pullout was applied to the screw head in the virtual models (Fig. 2A).

Compression. A rod (6 $\mathrm{mm}$ diameter and $30 \mathrm{~mm}$ long) of the same material was inserted into the screw head to allow this application of compressive force. A force of $50 \mathrm{~N}$ was applied to the opposite end of the screw head (Fig. 2B).

Flexion. In the same model a compression force of $50 \mathrm{~N}$ was applied at the opposite extremity to the screw head, $45^{\circ}$ in relation to the axis of the rod in the direction of the screw tip (Fig. 2C).

In this study the distribution of von Mises tension was evaluated in the polyurethane in thirteen adjacent points to the experimental model $(0.5 \mathrm{~mm}$ external screw thread

Table I. Dimensions of screws (mm).

\begin{tabular}{lccccc}
\hline Screw & Length & $\begin{array}{c}\text { External } \\
\text { Diameter }\end{array}$ & $\begin{array}{c}\text { Internal } \\
\text { Diameter }\end{array}$ & $\begin{array}{c}\text { Thread } \\
\text { Pitch }\end{array}$ & $\begin{array}{c}\text { Height of } \\
\text { thread }\end{array}$ \\
\hline Dual core - Single thread & 30 & 6.2 & $3.0^{*}-3.5^{*}$ & 2.75 & $1.35-1.6$ \\
Dual core - Double thread & 30 & 6.2 & $4.5^{*}-5.2^{*}$ & $4(2)^{* *}$ & $0.5-0.85$ \\
Cilíndrico & 30 & 6 & 4.8 & 1.75 & 0.6 \\
\hline
\end{tabular}

*Inside diameter cylindrical region; ** two parallel threads 
and $6 \mathrm{~mm}$ apart - Fig. 3A). Tensions generated in the screw along its inner diameter, in the upper region (30 points) in the central region (30 points) and in the lower region (30 points) were also evaluated (Fig. 3B).

Table II. Materials properties.

\begin{tabular}{lllll}
\hline & Material & $\mathbf{E}(\mathbf{G P a}) *$ & $\mathbf{v}^{* *}$ & Source \\
\hline Block & Polyurethane & 0.023 & 0.30 & Hsu et al. $(2005)$ \\
Screw & Titanium alloy & 114 & 0.30 & \\
\hline
\end{tabular}

*Modulus of elasticity; **Poisson's ratio
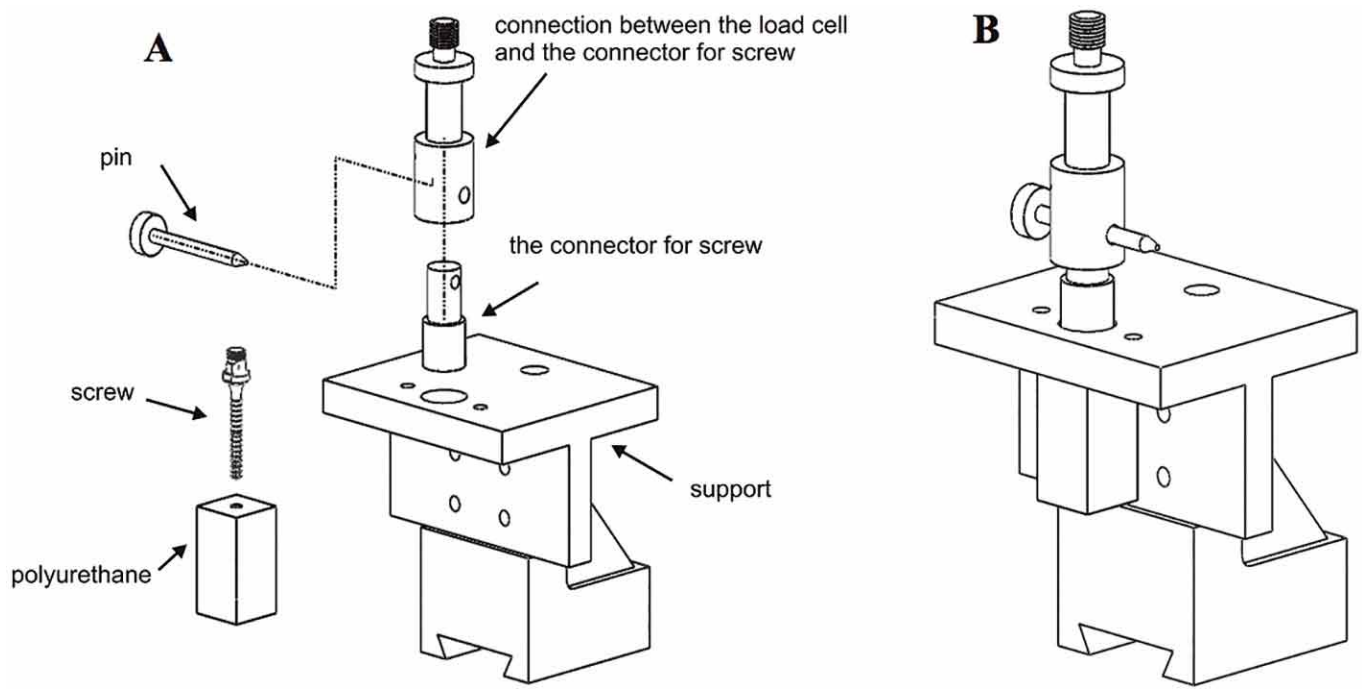

Fig. 1. Pullout test: Device (A) and force application (B).
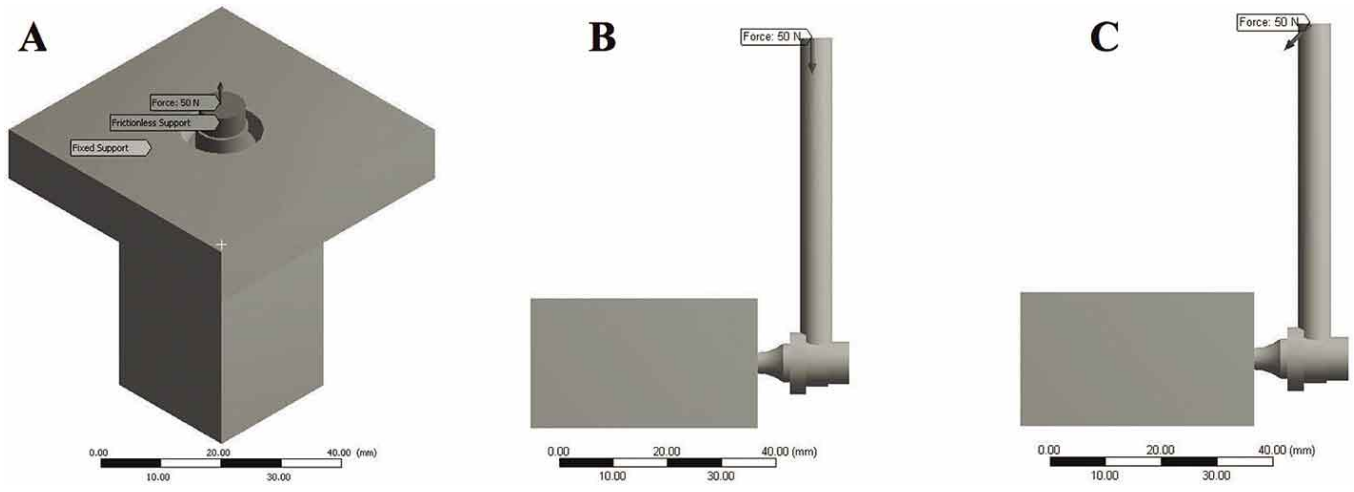

Fig. 2. Boundary conditions for applying pullout strength (A), compression (B) and flexion (C).

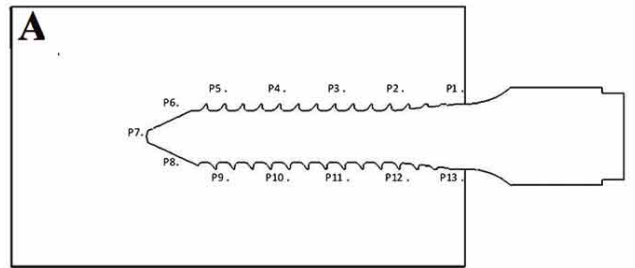

B

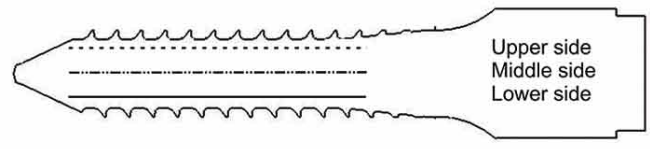

Fig. 3. Regions of tension analyzed in polyurethane (A) and the screw (B). 


\section{RESULTS}

The models were validated by simulation of the pullout force, evaluating the elastic region of the curve force $(\mathrm{N})$ versus displacement $(\mathrm{mm})$. The difference between trials in the universal testing machine (UTM) and the finite element method was $10.3 \%$ for G1, 9.5\% for G2 and $14.3 \%$ for G3 (Table III).

Table III. Stiffness of polyurethane/screw set.

\begin{tabular}{|c|c|c|c|}
\hline \multirow{2}{*}{ Group } & \multicolumn{2}{|c|}{ Stiffness (N/mm) } & \multirow{2}{*}{$\begin{array}{c}\text { Difference between methods } \\
(\%)\end{array}$} \\
\hline & MUE & MEF & \\
\hline G1 & 681.51 & 727.96 & $10.3 \%$ \\
\hline G2 & 848.07 & 737.73 & $9.5 \%$ \\
\hline G3 & 833.33 & 714.29 & $14.3 \%$ \\
\hline
\end{tabular}

While applying force in the direction of pullout it was possible to observe that the cylindrical screw was generating greater tension in polyurethane. The dual core screws generated equivalent tension levels (Fig. 4A). The highest tension levels were observed in the region next to the screw head (points 2 and 12) for all the screws head and also near the tip for the cylindrical screw (point 7).

When applying the compression and flexion force it was possible to observe that the cylindrical screw generated the highest tension in polyurethane. The dual core screws generated equivalent tension levels (Figs. 4B-C). The highest levels of tension were observed in the region near the screw head (points 1,2,12 and 13) and the tip (point 7) for all screws.

For the same force intensity $(\mathrm{F}=50 \mathrm{~N})$, the flexion force generated in the polyurethane is the highest, followed by compression. The tension generated by the force in the direction of the pullout is significantly lower than the others.

While evaluating the tension generated in the screw while applying different forces we observed higher levels of tension generated in the dual core screw with single thread. Equivalent tension levels were generated in the cylindrical screws and dual core double thread. The highest levels of tension were observed in the region near the screw head (Figs. 5, 6 and 7).
A

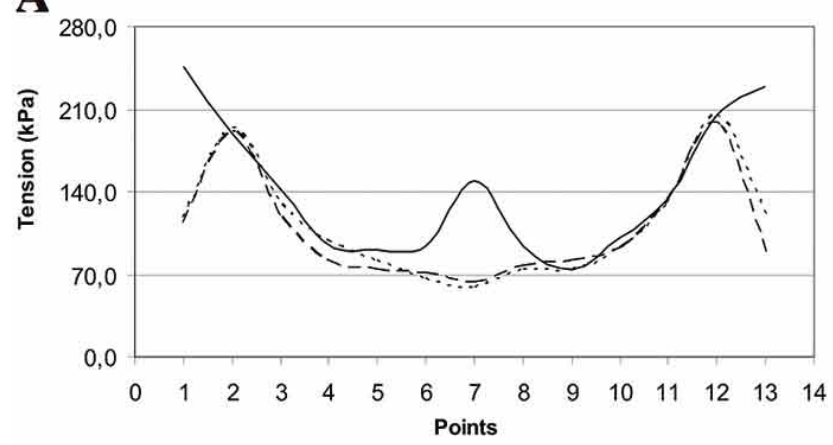

C

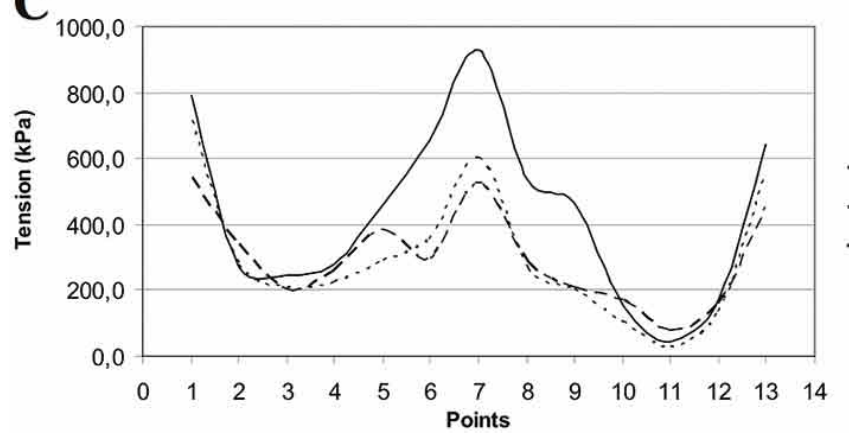

B

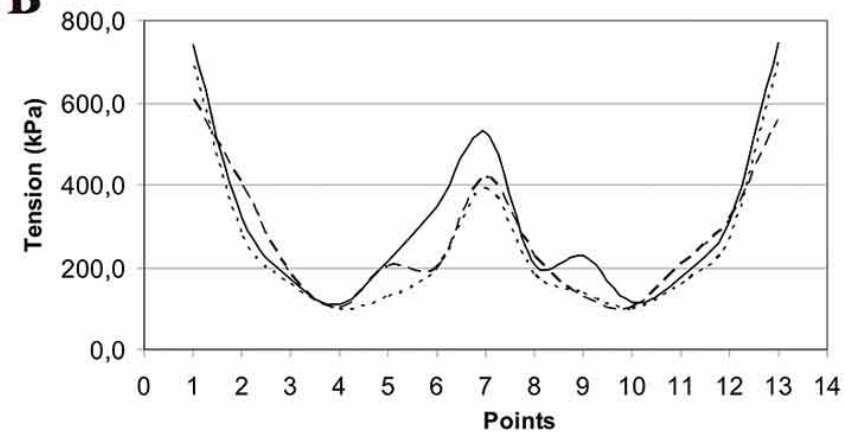

Fig. 4. Tension generated by the screw in polyurethane while applying force $(50 \mathrm{~N})$ in the direction of the pullout (A), compression (B) and flexion (C). 
A
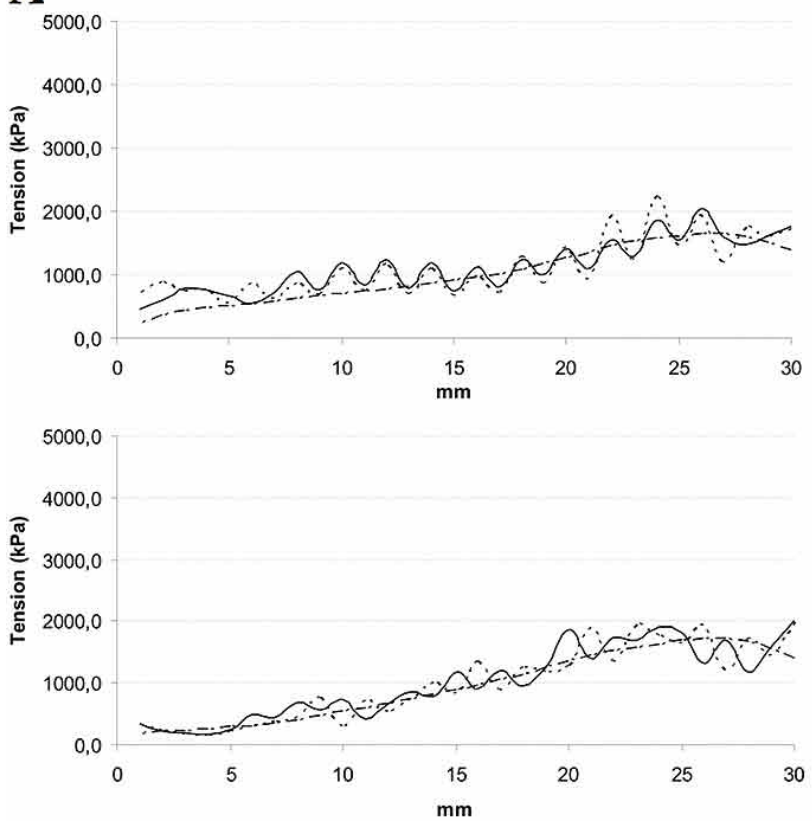

B
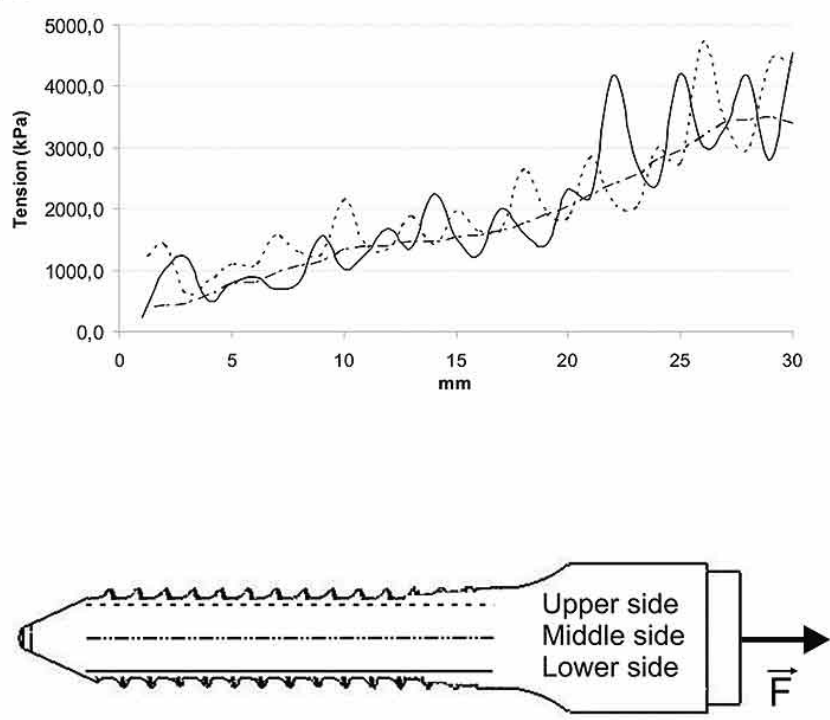

Fig. 5. Tension generated on the screw while applying a force in the direction of pullout of $50 \mathrm{~N}$. A: dual core screw - double thread; B: dual core screw - single thread; C: cylindrical screw.
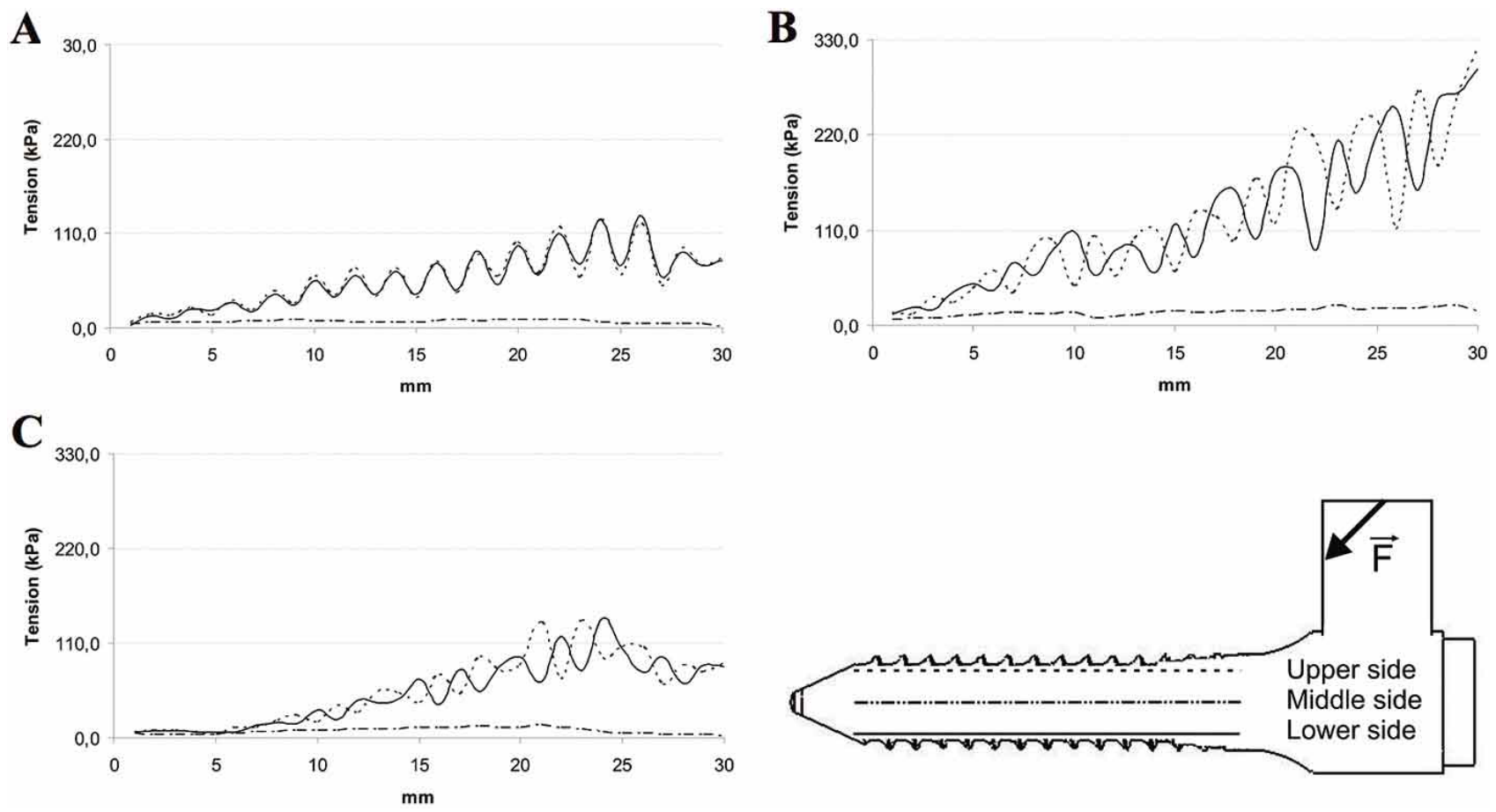

Fig. 6. Tension generated by the screw while applying a compression force of $50 \mathrm{~N}$. A: dual core screw - double thread; B: dual core screw - single thread; C: cylindrical screw. 

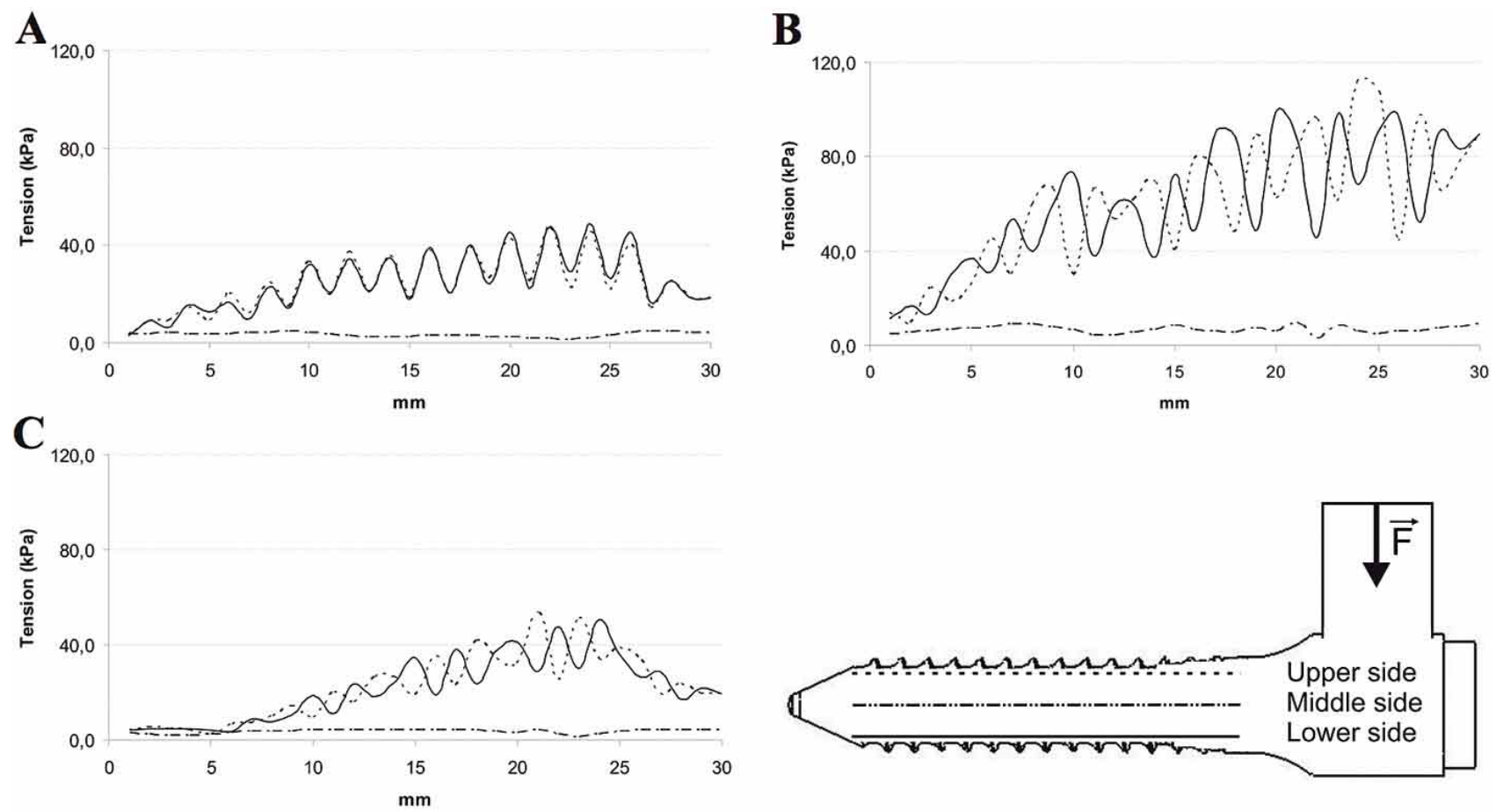

Fig. 7. Tension generated on the screw while applying a flexion force of $50 \mathrm{~N}$ : A: dual core screw - double thread; B: dual core screw single thread; C: cylindrical screw.

\section{DISCUSSION}

In this study we used the analysis by finite element method to evaluate the distribution of von Mises tension while applying pullout, compression, and flexion forces. To validate the experimental models, the relative rigidity during the elastic behavior, while applying a force in the direction of pullout for dual core (double and single thread) and cylindrical screws was evaluated (Hsu et al.). The results for validation are within the acceptable standard. Our results showed that the dual core screws had higher stiffness when compared to cylindrical screws. The same result has been found by other authors (Lill et al.; Seller et al.).

After validating the models it was possible to evaluate the tension distribution produced by screws, while applying different forces. Our results showed that the dual core screws produced low-tension in polyurethane when compared to the cylindrical screw. Regardless of the direction of force application and the screw design, higher levels of stress in the tip and screw head region were observed.

By observing the tension on the screw, we identified the highest levels of tension in the region corresponding to the first three threads near the screw head, and this tension gradually decreased to the region of the screw tip. This behavior was observed for all types of screws and forces studied. The screw that had lower levels of tension was the dual core - double thread and the higher in the dual core - single thread. This result may occur because the dual core screw - single thread presents the lower internal diameter among those studied. The dual core screw - double thread has a more robust internal diameter in the critical region nearest the screw head. We therefore believe that although a gain in pullout resistance with decreasing inner diameter, these screws may be more susceptible to failure since they present higher internal tension generated from the same applied force.

Considering the limitations of transferring the findings of this study to the clinical aspects, it should be highlighted that the screws' bore taper allow better adaptation to the vertebra due to sticking to the cancellous bone (Lill et al.). The previously mentioned studies involved structures with a tapered inner and outer diameter which had a reduction in fixation resistance, although with good clinical results (Daftari et al., 1994). Currently, models of screws such as those used in this study are 
composed of external cylindrical diameters and a internal conical, thus a progressive increase of the inner part occurs which means in clinical terms, the compression of the bone structure around the screw, thereby increasing the mechanical strength of the system (Inceoglu et al.; Seller et al.). Thus, the distribution of the stress conditions in the screw depends not only on the conditions of the interface, but also the loading mechanism and morphology of the vertebral structure considered.

Failure to anchor the implant is a medical condition commonly found in vertebral column surgeries (Lonstein et al., 1999). The literature presents several topics that influence the stability of the screw, including the composition and type of bone, bone mineral density, screw type and how it was inserted into the bone (Wittenberg et al., 1993). Accordingly, the sum of these factors influences the clinical choice (Oktenoglu et al., 2001). Studies seeking to assess the type of action performed by a specific spinal implant fixation are of paramount importance, since one can optimize the use of this orthotic device, mainly through indication of the appropriate size screw used in a given clinical condition without compromising the spinal canal.

Some studies show that bilateral placement of screws provides greater resistance to pullout when compared to the method of angled insertion, even when the screw has a short dimension (Dipaola et al., 2008; Patel et al., 2008). Other studies show that there is an ideal screw insertion angle, allowing greater pullout resistance (Kang et al., 2014; Patel et al., 2010). In loosening the screw bone interface, clinical (Vaccaro et al., 1998) and biomechanical (Panjabi et al., 1999) studies point to high tension, mainly at the lower end of the screw, and tension of the bone - screw interface increases with the angle of divergence of the screw.

Our study design has some limitations and our results can not be fully transferred to the human condition. Indeed, we recognize that a more realistic design should include human vertebrae. However, large variations in bone quality and the geometric characteristics of human vertebrae may compromise the results and validation of the finite element model (Chao et al., 2008; Hsu et al.; Kwok et al.; Lill et al.). Thus, many researchers have used synthetic models with regular geometry for comparing different designs of vertebrae screws (Hsu et al.; Kwok et al.; Lill et al.; Vaccaro et al.).

According to the limitations of this study and the methods used, it can be concluded that the use of screws with conical internal and cylindrical external diameter morphology is beneficial since the inner diameter of the thicker screw head is maintained because this region concentrates the major tension in the screw and consequently breakage may occur.

\section{ACKNOWLEDGEMENTS}

This project was supported by CAPES. The authors thank the Bioengineering Laboratory for the use of universal testing machine and the finite element analysis and $\mathrm{Mr}$ Reginaldo Trevilato da Silva for providing technical support during this work.

MACEDO, A. P.; ISSA, J. P. M.; DEFINO, H. L. A. \& SHIMANO, A. C. Evaluación biomecánica de un sistema de fijación espinal con tornillo por el método de elementos finitos. Int. J. Morphol., 33(1):318-326, 2015.

RESUMEN: El objetivo de la presente investigación fue validar modelos virtuales para el estudio de tornillos cilíndricos y de pedículo de doble núcleo para evaluar la influencia de la geometría éstos en su anclaje y comportamiento mecánico. Se utilizaron dos modelos de tornillos de doble núcleo, unos de rosca doble y otros de rosca única, ambos tipos conformados por un tornillo cilíndrico convencional. La rigidez se evaluó en una prueba de retirada, utilizando poliuretano. Se crearon tres modelos virtuales tridimensionales que permitieron simular la prueba de retirada para el análisis de elementos finitos. Para validar los modelos, los resultados se correlacionaron con ensayos mecánicos. Se estudiaron las tensiones generadas en el poliuretano y el tornillo a través de la simulación de la aplicación de la fuerza en la dirección de retirada del tornillo, de la fuerza transmitida por la varilla en el individuo en reposo de pie, y la fuerza transmitida por la varilla cuando se realizaba la flexión del tronco. Los tornillos de doble núcleo generan tensiones más bajas en el poliuretano en comparación con el tornillo cilíndrico, para las mismas fuerzas estudiadas. Cuando se evalúa la tensión interna en el tornillo, se presentaron niveles más bajos de tensión en el tornillo de doble rosca, en comparación a los niveles de tensión más altos presentados en los tornillos de rosca única, presentando este tornillo un diámetro interno más pequeño que puede ser responsable de la mayor tensión. Los tornillos de doble núcleo y doble rosca proporcionan un buen anclaje con mayor diámetro y tensión en la región a tratar, evitando la fractura.

PALABRAS CLAVE: Tornillos; Dispositivos de fijación de la columna vertebral; Método de elementos finitos. 


\section{REFERENCES}

Abshire, B. B.; McLain, R. F.; Valdevit, A. \& Kambic, H. E. Characteristics of pullout failure in conical and cylindrical pedicle screws after full insertion and back-out. Spine J., $1(6): 408-14,2001$.

Brantley, A. G.; Mayfield, J. K.; Koeneman, J. B. \& Clark, K. R. The effects of pedicle screw fit. An in vitro study. Spine (Phila Pa 1976), 19(15):1752-8, 1994.

Chao, C. K.; Hsu, C. C.; Wang, J. L. \& Lin, J. Increasing bending strength and pullout strength in conical pedicle screws: biomechanical tests and finite element analyses. J. Spinal Disord. Tech., 21(2):130-8, 2008.

Chen, P. Q.; Lin, S. J.; Wu, S. S. \& So, H. Mechanical performance of the new posterior spinal implant: effect of materials, connecting plate, and pedicle screw design. Spine (Phila Pa 1976), 28(9):881-6, 2003a.

Chen, S. I.; Lin, R. M. \& Chang, C. H. Biomechanical investigation of pedicle screw-vertebrae complex: a finite element approach using bonded and contact interface conditions. Med. Eng. Phys., 25(4):275-82, 2003 a.

Coe, J. D.; Warden, K. E.; Herzig, M. A. \& McAfee, P. C. Influence of bone mineral density on the fixation of thoracolumbar implants. A comparative study of transpedicular screws, laminar hooks, and spinous process wires. Spine (Phila Pa 1976), 15(9):902-7, 1990.

Daftari, T. K.; Horton, W. C. \& Hutton, W. C. Correlations between screw hole preparation, torque of insertion, and pullout strength for spinal screws. J. Spinal Disord., 7(2):139-45, 1994.

Dipaola, C. P.; Jacobson, J. A.; Awad, H.; Conrad, B. P. \& Rechtine, G. R. 2nd. Screw orientation and plate type (variable- vs. fixed-angle) effect strength of fixation for in vitro biomechanical testing of the Synthes CSLP. Spine J., 8(5):717-22, 2008.

George, D. C.; Krag, M. H.; Johnson, C. C.; Van Hal, M. E.; Haugh, L. D. \& Grobler, L. J. Hole preparation techniques for transpedicle screws. Effect on pull-out strength from human cadaveric vertebrae. Spine (Phila Pa 1976), 16(2):181-4, 1991.

Hackenberg, L.; Link, T. \& Liljenqvist, U. Axial and tangential fixation strength of pedicle screws versus hooks in the thoracic spine in relation to bone mineral density. Spine (Phila Pa 1976), 27(9):937-42, 2002.

Hirano, T.; Hasegawa, K.; Takahashi, H. E.; Uchiyama, S.; Hara, T.; Washio, T.; Sugiura, T.; Yokaichiya, M. \& Ikeda, M. Structural characteristics of the pedicle and its role in screw stability. Spine (Phila Pa 1976), 22(21):2504-9, 1997.
Hsu, C. C.; Chao, C. K.; Wang, J. L.; Hou, S. M.; Tsai, Y. T. \& Lin, J. Increase of pullout strength of spinal pedicle screws with conical core: biomechanical tests and finite element analyses. J. Orthop. Res., 23(4):788-94, 2005.

Inceoglu, S.; Ferrara, L. \& McLain, R. F. Pedicle screw fixation strength: pullout versus insertional torque. Spine J., 4(5):5138, 2004.

Kang, D. G.; Lehman, R. A. Jr.; Bevevino, A. J.; Gaume, R. E.; Purcell, R. L.; Dmitriev, A. E. \& Lenke, L. G. Pedicle screw "hubbing" in the immature thoracic spine: a biomechanical and micro-computed tomography evaluation. J. Pediatr. Orthop., 34(7):703-9, 2014.

Kostuik, J. P.; Munting, E. \& Valdevit, A. Biomechanical analysis of screw load sharing in pedicle fixation of the lumbar spine. J. Spinal Disord., 7(5):394-401, 1994.

Krenn, M. H.; Piotrowski, W. P.; Penzkofer, R. \& Augat, P. Influence of thread design on pedicle screw fixation. Laboratory investigation. J. Neurosurg. Spine, 9(1):90-5, 2008 .

Kwok, A. W.; Finkelstein, J. A.; Woodside, T.; Hearn, T. C. \& $\mathrm{Hu}, \mathrm{R}$. W. Insertional torque and pull-out strengths of conical and cylindrical pedicle screws in cadaveric bone. Spine (Phila Pa 1976), 21(21):2429-34, 1996.

Law, M.; Tencer, A. F. \& Anderson, P. A. Caudo-cephalad loading of pedicle screws: mechanisms of loosening and methods of augmentation. Spine (Phila Pa 1976), 18(16):2438-43, 1993.

Lill, C. A.; Schneider, E.; Goldhahn, J.; Haslemann, A. \& Zeifang, F. Mechanical performance of cylindrical and dual core pedicle screws in calf and human vertebrae. Arch. Orthop. Trauma Surg., 126(10):686-94, 2006.

Lonstein, J. E.; Denis, F.; Perra, J. H.; Pinto, M. R.; Smith, M. D. \& Winter, R. B. Complications associated with pedicle screws. J. Bone Joint Surg. Am., 81(11):1519-28, 1999.

Oktenoglu, B. T.; Ferrara, L. A.; Andalkar, N.; Ozer, A. F.; Sarioglu, A. C. \& Benzel, E. C. Effects of hole preparation on screw pullout resistance and insertional torque: a biomechanical study. J. Neurosurg., 94(1 Suppl.):91-6, 2001.

Ono, A.; Brown, M. D.; Latta, L. L.; Milne, E. L. \& Holmes, D. C. Triangulated pedicle screw construct technique and pullout strength of conical and cylindrical screws. J. Spinal Disord., 14(4):323-9, 2001.

Panjabi, M. M.; Isomi, T. \& Wang, J. L. Loosening at the screwvertebra junction in multilevel anterior cervical plate constructs. Spine (Phila Pa 1976), 24(22):2383-8, 1999. 
Patel, P. S.; Shepherd, D. E. \& Hukins, D. W. Compressive properties of commercially available polyurethane foams as mechanical models for osteoporotic human cancellous bone. B. M. C. Musculoskelet. Disord., 9:137, 2008.

Patel, P. S.; Shepherd, D. E. \& Hukins, D. W. The effect of screw insertion angle and thread type on the pullout strength of bone screws in normal and osteoporotic cancellous bone models. Med. Eng. Phys., 32(8):822-8, 2010.

Seller, K.; Wahl, D.; Wild, A.; Krauspe, R.; Schneider, E. \& Linke, B. Pullout strength of anterior spinal instrumentation: a product comparison of seven screws in calf vertebral bodies. Eur. Spine J., 16(7):1047-54, 2007.

Vaccaro, A. R.; Falatyn, S. P.; Scuderi, G. J.; Eismont, F. J.; McGuire, R. A.; Singh, K. \& Garfin, S. R. Early failure of long segment anterior cervical plate fixation. J. Spinal Disord., 11(5):410-5, 1998.

Wittenberg, R. H.; Lee, K. S.; Shea, M.; White, A. A. 3rd. \& Hayes, W. C. Effect of screw diameter, insertion technique, and bone cement augmentation of pedicular screw fixation strength. Clin. Orthop. Relat. Res., (296):278-87, 1993.

Zdeblick, T. A.; Kunz, D. N.; Cooke, M. E. \& McCabe, R. Pedicle screw pullout strength. Correlation with insertional torque. Spine (Phila Pa 1976), 18(12):1673-6, 1993.
Correspondence to:

Ana Paula Macedo

Department of Biomechanics

Medicine and Rehabilitation of the Locomotor Apparatus

Faculty of Medicine of Ribeirão Preto

University of São Paulo

Av. Bandeirantes, 3900

Monte Alegre

Ribeirão Preto, CEP: 14049-900, SP

BRAZIL

Email: anapaula@forp.usp.br

Received: 23-10-2014

Accepted: 14-01-2015 